\title{
Article
}

\section{Influence of hematite morphology on the CO oxidation performance of $\mathrm{Au} / \alpha-\mathrm{Fe}_{2} \mathrm{O}_{3}$}

\author{
Yanan Gao a, Fu-Kuo Chiang b, Shaojie Li ${ }^{a}$, Long Zhang a, Peng Wang a,b, Emiel J. M. Hensen a,* \\ a Laboratory of Inorganic Materials and Catalysis, Department of Chemical Engineering and Chemistry, Eindhoven University of Technology, P.O. Box 513, \\ 5600 MB Eindhoven, The Netherlands \\ b National Institute of Clean-and-Low-Carbon Energy, Shenhua NICE, Future Science and Technology City, Beijing 102211, China
}

\section{A R T I C L E I N F}

\section{Article history:}

Received 1 May 2020

Accepted 5 June 2020

Available online 5 September 2020

\section{Keywords:}

Gold

CO oxidation

Hematite

Morphology

Stability

\begin{abstract}
A B S T R A C T
Controlling the interaction between metal nanoparticles and the support is a means to tune catalytic activity and stability. Herein we investigated the influence of the morphology of hematite on the performance of gold for $\mathrm{CO}$ oxidation. Nanosphere and nanorod forms of hematite, $\alpha-\mathrm{Fe}_{2} \mathrm{O}_{3}(\mathrm{~S})$ and $\alpha-\mathrm{Fe}_{2} \mathrm{O}_{3}(\mathrm{R})$ respectively, were used to support gold nanoparticles. The surface of $\alpha-\mathrm{Fe}_{2} \mathrm{O}_{3}(\mathrm{R})$ was more corrugated than that of $\alpha-\mathrm{Fe}_{2} \mathrm{O}_{3}(\mathrm{~S})$. These defects provide anchoring sites for gold nanoparticle deposition and stabilization. Due to the stronger gold-support interactions, $\mathrm{Au} / \alpha-\mathrm{Fe}_{2} \mathrm{O}_{3}(\mathrm{R})$ contained smaller and more hemispherical gold particles than $\mathrm{Au} / \alpha-\mathrm{Fe}_{2} \mathrm{O}_{3}(\mathrm{~S})$. $\mathrm{Au} / \alpha-\mathrm{Fe}_{2} \mathrm{O}_{3}(\mathrm{R})$ was not only more active in $\mathrm{CO}$ oxidation but also much more stable as evident from the small change in gold particle size during reaction. The higher reducibility of $\mathrm{Au} / \alpha-\mathrm{Fe}_{2} \mathrm{O}_{3}(\mathrm{R})$ also contributed to the higher CO oxidation activity.
\end{abstract}

(C) 2021, Dalian Institute of Chemical Physics, Chinese Academy of Sciences. Published by Elsevier B.V. All rights reserved.

\section{Introduction}

Supported gold nanoparticle (AuNP) catalysts have attracted substantial attention in the field of oxidation reactions due to their unique catalytic properties [1-8]. CO oxidation is of special interest, not only because of its importance in practical applications such as automotive emissions control, but also because this simple reaction is an ideal model reaction to investigate important mechanistic aspects underlying the relation between catalytic activity and the nature of the active phase. Preferred supports for heterogeneous gold catalysts are metal oxides. The catalytic properties of such gold catalysts are controlled by many factors such as the size of gold nanoparticles, the oxidation state of gold and the interaction between gold and the support. These metal-support interactions affect the gold active phase through charge transfer, which is augmented when the support is reducible. The mechanism of $\mathrm{CO}$ oxidation can also change from a Langmuir-Hinshelwood one, in which $\mathrm{CO}$ and $\mathrm{O}_{2}$ adsorb on the gold phase, to a Mars-Van Krevelen one involving $\mathrm{O}$ atoms of a reducible oxide support. The gold-support interactions will also influence the particle size of the gold active phase and the sintering stability during high-temperature reactions.

Several strategies have been adopted for the development of metal-oxide supports in gold catalysis. The chemical composition of the metal oxide support influences the activity of the final supported gold catalyst through their textural and surface properties (e.g., $\mathrm{CeO}_{2}$ [9-12], $\mathrm{TiO}_{2}$ [13-16], $\mathrm{MnO}_{x}$ [17-19], $\mathrm{FeO}_{x}$ [20-24]). It is also possible to tune the crystal phase [25] or crystal size of a given metal oxide support [26]. Very small support particles can for instance give rise to different chemical properties through the increased exposure of defect sites. Also the surfaces exposed by a particular metal oxide crystal can be controlled, which is often expressed by the morphology of the

\footnotetext{
* Corresponding author. E-mail: e.j.m.hensen@tue.nl DOI: 10.1016/S1872-2067(20)63687-7 | http://www.sciencedirect.com/science/journal/18722067 | Chin. J. Catal., Vol. 42, No. 4, April 2021
} 
primary particles of the oxide support. This can also lead to profoundly different surface properties in terms of meal-support interactions and support reducibility. Many efforts have been made in this direction. For example, the influence of the shape/morphology of $\mathrm{CeO}_{2}$ has been extensively studied in the context of gold-catalyzed CO oxidation [27-31]. Huang and co-authors reported that ceria nanorods showed a much higher gold dispersion than gold on conventional ceria, explaining the higher $\mathrm{CO}$ oxidation activity [28]. Ceria shapes such as rods, cubes, and polyhedra were found to exhibit strongly different activities in the preferential oxidation of $\mathrm{CO}$ in $\mathrm{H}_{2}$ catalyzed by gold [30]. $\alpha-\mathrm{Fe}_{2} \mathrm{O}_{3}$ (hematite) is a thermally stable and environmentally benign support, which has not been explored as extensively yet for gold catalysis as ceria. $\mathrm{Gu}$ and co-workers deposited gold on three $\alpha-\mathrm{Fe}_{2} \mathrm{O}_{3}$ forms (truncated hexagonal bipyramid, quasi cubic, and hexagonal plate) and discovered that the size and size distribution of the gold particles were not affected by the morphology of $\alpha-\mathrm{Fe}_{2} \mathrm{O}_{3}$. However, the different $\mathrm{Au} / \alpha-\mathrm{Fe}_{2} \mathrm{O}_{3}$ interface structures related to the presence of different exposed crystal facets governed the activity differences observed in $\mathrm{CO}$ oxidation [32]. In this work, we synthesized two $\alpha-\mathrm{Fe}_{2} \mathrm{O}_{3}$ oxides with different shapes (nanorods and nanospheres) and loaded them with gold nanoparticles using a deposition-precipitation method. The results show that the size and size distribution of gold particles are dependent on the morphology of $\alpha-\mathrm{Fe}_{2} \mathrm{O}_{3}$, contributing to significant activity and stability differences in $\mathrm{CO}$ oxidation.

\section{Experimental}

\subsection{Catalyst preparation}

$\alpha-\mathrm{Fe}_{2} \mathrm{O}_{3}$ nanorods were synthesized using a modified hydrothermal method as reported by Jia and co-workers [33]. $12.8 \mathrm{~mL}$ of aqueous $\mathrm{FeCl}_{3}$ solution $(0.5 \mathrm{M}), 11.6 \mathrm{~mL}$ of aqueous $\mathrm{NH}_{4} \mathrm{H}_{2} \mathrm{PO}_{4}$ solution $(0.02 \mathrm{M})$, and $296 \mathrm{~mL}$ of deionized $\mathrm{H}_{2} \mathrm{O}$ were mixed and stirred vigorously. Then, the mixed solution was transferred to a Teflon-lined stainless-steel autoclave for hydrothermal treatment at $220^{\circ} \mathrm{C}$ for $7 \mathrm{~h}$. After the autoclave was cooled to room temperature, the red solid was collected by decanting and centrifugation, followed by washing with deionized water three times and absolute ethanol twice. The solid was dried at $60{ }^{\circ} \mathrm{C}$ overnight in air before further use. The $\alpha-\mathrm{Fe}_{2} \mathrm{O}_{3}$ nanorods were denoted as $\alpha-\mathrm{Fe}_{2} \mathrm{O}_{3}(\mathrm{R})$.

$\alpha-\mathrm{Fe}_{2} \mathrm{O}_{3}$ nanospheres were synthesized using a hydrothermal method developed by ourselves using $\mathrm{Fe}\left(\mathrm{NO}_{3}\right)_{3}$ as iron precursor. $12.8 \mathrm{~mL}$ of aqueous $\mathrm{Fe}\left(\mathrm{NO}_{3}\right)_{3}$ solution $(0.5 \mathrm{M}), 11.6$ $\mathrm{mL}$ of aqueous $\mathrm{NH}_{4} \mathrm{H}_{2} \mathrm{PO}_{4}$ solution $(0.02 \mathrm{M})$, and $296 \mathrm{~mL}$ of deionized $\mathrm{H}_{2} \mathrm{O}$ were mixed and stirred vigorously. Then, the mixed solution was transferred to a Teflon-lined stainless-steel autoclave for hydrothermal treatment at $220{ }^{\circ} \mathrm{C}$ for $24 \mathrm{~h}$. The following treatment was the same as that of $\alpha-\mathrm{Fe}_{2} \mathrm{O}_{3}$ nanorods. The $\alpha-\mathrm{Fe}_{2} \mathrm{O}_{3}$ nanospheres were denoted as $\alpha-\mathrm{Fe}_{2} \mathrm{O}_{3}(\mathrm{~S})$.

Gold was deposited on the $\alpha-\mathrm{Fe}_{2} \mathrm{O}_{3}$ supports through a deposition-precipitation method using urea as the precipitation agent [34]. Typically, $1.2 \mathrm{~g}$ of $\alpha-\mathrm{Fe}_{2} \mathrm{O}_{3}$ and $0.36 \mathrm{~g}$ of urea were added to a round-bottom flask, to which $40 \mathrm{ml}$ of $\mathrm{HAuCl}_{4}(1.5$
mmol/L) was added. Afterwards, the mixture was stirred and heated to $90{ }^{\circ} \mathrm{C}$ in an oil bath and kept at this temperature for $20 \mathrm{~h}$ under reflux. The flask was covered with aluminum foil to avoid exposure to light. Afterwards, the mixture was cooled to room temperature and filtered with deionized water. The obtained solid was dried at $60{ }^{\circ} \mathrm{C}$ overnight in air without further calcination. The targeted gold loading was $1.0 \mathrm{wt} \%$. The as-prepared gold catalysts are denoted as $\mathrm{Au} / \alpha-\mathrm{Fe}_{2} \mathrm{O}_{3}(\mathrm{R})$ and $\mathrm{Au} / \alpha-\mathrm{Fe}_{2} \mathrm{O}_{3}(\mathrm{~S})$, respectively.

\subsection{Catalyst characterization}

The textural properties of the materials were measured by a Tristar 3000 automated gas adsorption system. The samples were degassed at $120{ }^{\circ} \mathrm{C}$ overnight before analysis. The $\mathrm{Au}$ loading was determined by Inductively Coupled Plasma Optical Emission Spectroscopy (ICP-OES) after extraction of gold in aqua regia.

X-ray diffraction (XRD) patterns were collected on a Bruker D2 Phase powder diffraction system with $\mathrm{Cu} K_{\alpha}$ radiation. X-ray photoelectron spectroscopy (XPS) measurements were carried out with a Thermo Scientific K-Alpha spectrometer. Spectra were obtained using an aluminum anode (Al $K_{\alpha}=1486.6 \mathrm{eV}$ ) operating at $72 \mathrm{~W}$ and a spot size of $400 \mu \mathrm{m}$. The background pressure was $2 \times 10^{-9}$ mbar and during measurement $3 \times 10^{-7}$ mbar Ar. Data analysis was performed using CasaXPS software. The binding energy was corrected for surface charging by taking the $\mathrm{C} 1 \mathrm{~s}$ peak of contaminant carbon as a reference at 284.6 $\mathrm{eV}$.

Scanning electron microscopy (SEM) was carried out using a FEI Quanta 200F scanning electron microscope. TEM and STEM images of various samples were acquired by a Cs probe -corrected JEOL JEM ARM200F operated at $200 \mathrm{kV}$ for all analyses. All samples were prepared by dispersing the ground material powder in ethanol and a few drops were placed onto copper grids supported on lacey carbon films.

IR measurements were performed on a home-built in situ setup employing a Bruker Vertex 70v Fourier-Transform infrared spectrometer equipped with a DTGS detector. Prior to measurement, the sample was first treated in flowing He at 120 ${ }^{\circ} \mathrm{C}$ for $2 \mathrm{~h}$ with a heating rate of $10{ }^{\circ} \mathrm{C} / \mathrm{min}$. Then the cell was cooled and outgassed until a residual pressure of $5 \times 10^{-5} \mathrm{mbar}$ was reached. For pyridine adsorption, pyridine was introduced from an ampoule at its vapor pressure at room temperature. The exposure time was $10 \mathrm{~min}$. Subsequently, the cell was evacuated to a pressure of lower than $5 \times 10^{-6}$ mbar and a spectrum was recorded at $120^{\circ} \mathrm{C}$. In order to quantify the amount of Lewis acid sites, the molar extinction coefficient value of $1.11 \mathrm{~cm} \cdot \mathrm{mol}^{-1}$ was applied.

\subsection{Catalytic activity measurements}

CO oxidation activity measurements were performed in a high-throughput setup equipped with 10 parallel reactor channels at atmospheric pressure. $50 \mathrm{mg}$ of sieved sample with a fraction of 125-250 um was mixed with $200 \mathrm{mg} \mathrm{SiC}$ as a diluent in a quartz reactor. The catalyst was pretreated in a $\mathrm{He}$ 


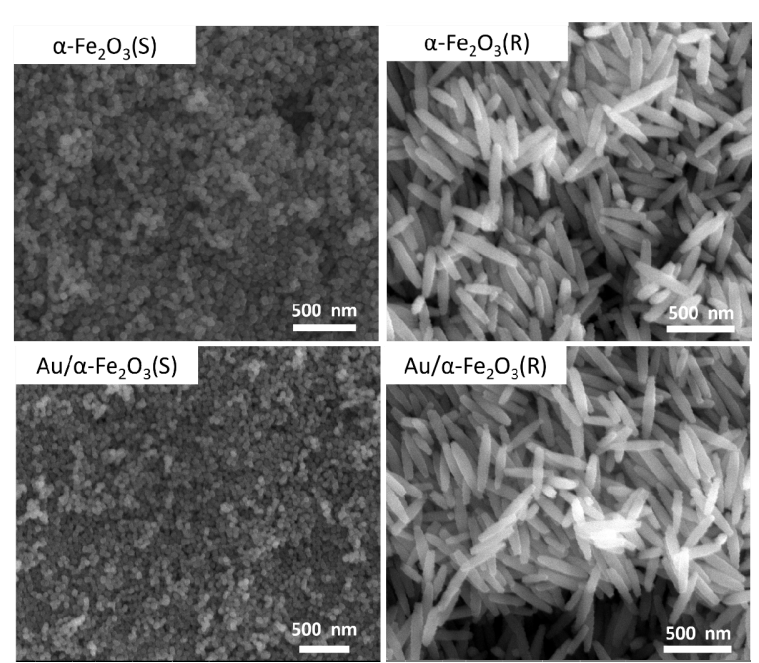

Fig. 1. SEM images of $\alpha-\mathrm{Fe}_{2} \mathrm{O}_{3}(\mathrm{~S}), \alpha-\mathrm{Fe}_{2} \mathrm{O}_{3}(\mathrm{R})$ and corresponding fresh gold catalysts.

flow of $50 \mathrm{ml} / \mathrm{min}$ for $2 \mathrm{~h}$ at $25^{\circ} \mathrm{C}$. The feed mixture consisted of $1 \mathrm{vol} \% \mathrm{CO}$ and 1 vol\% $\mathrm{O}_{2}$ balanced with He (total flow 50 $\mathrm{ml} / \mathrm{min}$ per reactor). Three catalytic cycles were performed to evaluate the activity and stability of the catalysts. In the first cycle, the reaction temperature was raised from 25 to $300{ }^{\circ} \mathrm{C}$ in steps of $25{ }^{\circ} \mathrm{C}$ using a rate of $5{ }^{\circ} \mathrm{C} / \mathrm{min}$. The desired temperature was held for $30 \mathrm{~min}$ to reach a steady state. After the test, the oven was cooled to $25^{\circ} \mathrm{C}$, followed by another cycle using the same temperature program. The effluent gas was analyzed by online gas chromatography with an Interscience Compact GC equipped with Porapak Q (TCD) and Molecular sieve 5A (TCD) columns.

\section{Results and discussion}

Fig. 1 shows representative SEM images of as-synthesized $\alpha-\mathrm{Fe}_{2} \mathrm{O}_{3}(\mathrm{~S})$ and $\alpha-\mathrm{Fe}_{2} \mathrm{O}_{3}(\mathrm{R})$. The size of the sphere-like particles of $\alpha-\mathrm{Fe}_{2} \mathrm{O}_{3}(\mathrm{~S})$ is $\sim 50 \mathrm{~nm}$. $\alpha-\mathrm{Fe}_{2} \mathrm{O}_{3}(\mathrm{R})$ is made up from rod-shaped $\alpha-\mathrm{Fe}_{2} \mathrm{O}_{3}$ with a diameter of $\sim 70 \mathrm{~nm}$ and a length of 300-500 nm. As expected, adding gold did not change the morphology of the parent $\alpha-\mathrm{Fe}_{2} \mathrm{O}_{3}$ supports. The XRD patterns shown in Fig. 2 confirm that both supports are hematite $\left(\alpha-\mathrm{Fe}_{2} \mathrm{O}_{3}\right)$. The absence of diffraction peaks due to gold indicates a high gold dispersion. Data about the surface areas and

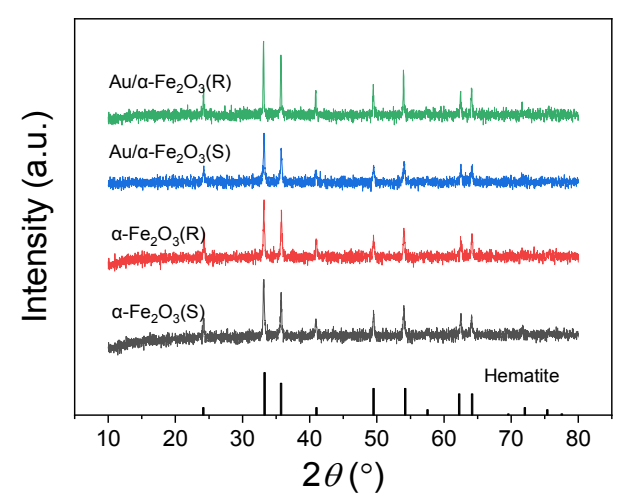

Fig. 2. XRD patterns of $\alpha-\mathrm{Fe}_{2} \mathrm{O}_{3}(\mathrm{~S}), \alpha-\mathrm{Fe}_{2} \mathrm{O}_{3}(\mathrm{R})$ and corresponding fresh gold catalysts.
Table 1

Physicochemical properties of $\mathrm{Au} / \alpha-\mathrm{Fe}_{2} \mathrm{O}_{3}$ catalysts.

\begin{tabular}{lcccc}
\hline Material & $S_{\text {BET }}\left(m^{2} / g\right)$ & {$[\mathrm{Au}]^{\mathrm{a}}(\mathrm{wt} \%)$} & $D_{\mathrm{Au}}{ }^{\mathrm{b}}(\mathrm{nm})$ & $D_{\mathrm{Au}}{ }^{\mathrm{c}}(\mathrm{nm})$ \\
\hline $\mathrm{Au} / \alpha-\mathrm{Fe}_{2} \mathrm{O}_{3}(\mathrm{~S})$ & 26 & 1.01 & $2.0 \pm 0.5$ & $4.0 \pm 1.8$ \\
$\mathrm{Au} / \alpha-\mathrm{Fe}_{2} \mathrm{O}_{3}(\mathrm{R})$ & 15 & 1.03 & $1.5 \pm 0.3$ & $2.4 \pm 0.7$ \\
\hline
\end{tabular}

a Determined by ICP-OES. ${ }^{\mathrm{b}}$ Average AuNP size of fresh catalysts, determined by HAADF-STEM. ${ }^{c}$ Used catalysts, determined by HAADF-STEM.

gold loading are listed in Table 1. The BET surface areas of $\mathrm{Au} / \alpha-\mathrm{Fe}_{2} \mathrm{O}_{3}(\mathrm{~S})$ and $\mathrm{Au} / \alpha-\mathrm{Fe}_{2} \mathrm{O}_{3}(\mathrm{R})$ are 26 and $15 \mathrm{~m}^{2} / \mathrm{g}$, respectively. The measured gold loading is close to the targeted value of 1 wt $\%$, indicating the high efficiency of the deposition-precipitation method.

TEM and HAADF-STEM measurements were performed in order to investigate the surface structure of $\alpha-\mathrm{Fe}_{2} \mathrm{O}_{3}$ supports and the morphology of the supported gold particles, as shown in Fig. 3 and Fig. S1. The EM analysis reveals that the surface of $\alpha-\mathrm{Fe}_{2} \mathrm{O}_{3}(\mathrm{R})$ is much more corrugated than the surface of $\alpha-\mathrm{Fe}_{2} \mathrm{O}_{3}(\mathrm{~S})$. Thus, $\alpha-\mathrm{Fe}_{2} \mathrm{O}_{3}(\mathrm{R})$ should contain more surface defects. (110) and (104) facets can be observed in high-resolution HAADF-STEM images on $\alpha-\mathrm{Fe}_{2} \mathrm{O}_{3}(\mathrm{~S})$ and $\alpha-\mathrm{Fe}_{2} \mathrm{O}_{3}(\mathrm{R})$, respectively. Nevertheless, we cannot firmly conclude on the basis of these data that the hematite particles preferentially expose these facets. AuNPs with an average size of $2.0 \mathrm{~nm}$ are distributed over the surface of $\alpha-\mathrm{Fe}_{2} \mathrm{O}_{3}(\mathrm{~S})$. Their size distribution is not uniform and, from the shape of the particles in HAADF-STEM images, we can infer that the gold-support inter-
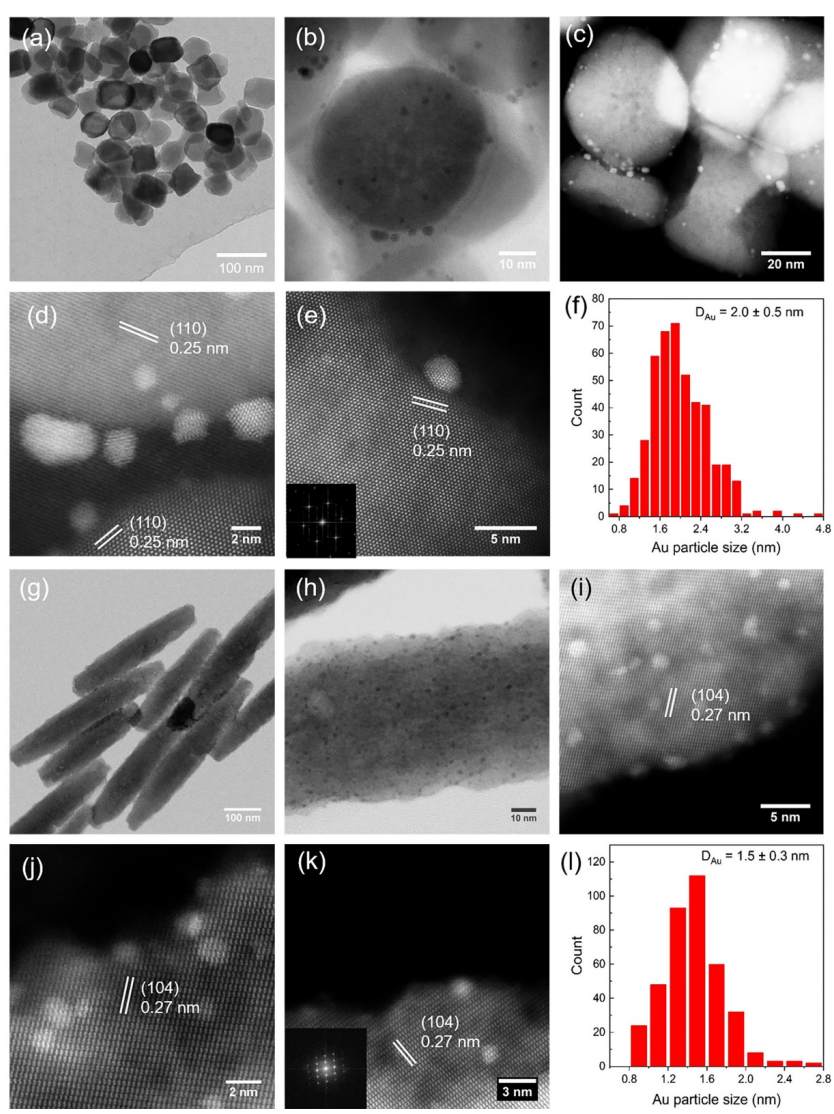

Fig. 3. TEM, HAADF-STEM images and gold particle size distribution of fresh $\mathrm{Au} / \alpha-\mathrm{Fe}_{2} \mathrm{O}_{3}(\mathrm{~S})(\mathrm{a}-\mathrm{f})$ and $\mathrm{Au} / \alpha-\mathrm{Fe}_{2} \mathrm{O}_{3}(\mathrm{R})$ (g-l) catalyst. 

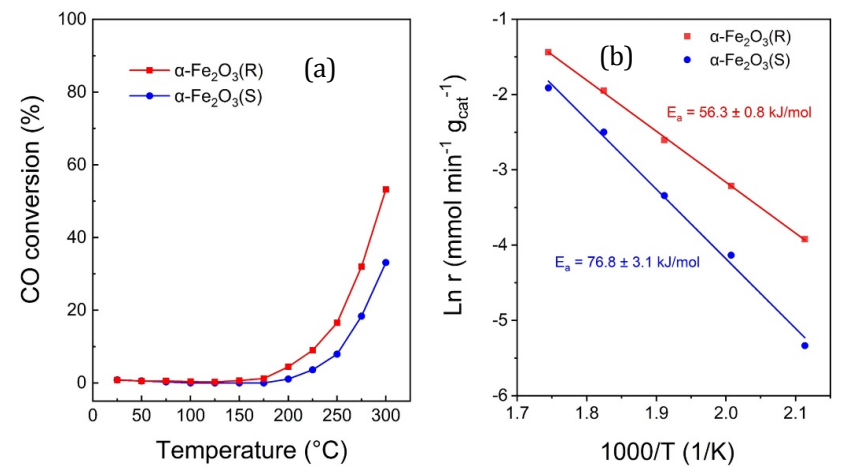

Fig. 4. $\mathrm{CO}$ oxidation activity (a) and Arrhenius plot (b) of $\alpha-\mathrm{Fe}_{2} \mathrm{O}_{3}(\mathrm{~S})$ and $\alpha-\mathrm{Fe}_{2} \mathrm{O}_{3}(\mathrm{R})$. Reaction conditions: $50 \mathrm{mg}$ sample, 1 vol\% CO, 1 vol\% $\mathrm{O}_{2}$ balanced with $\mathrm{He}$, total flow rate $50 \mathrm{ml} / \mathrm{min}$.

actions are weaker in this sample as compared to $\mathrm{Au} / \alpha-\mathrm{Fe}_{2} \mathrm{O}_{3}(\mathrm{R})$. In the latter sample, a more uniform size distribution of AuNPs is observed with a mean size of $1.5 \mathrm{~nm}$. The stronger gold-support interaction for $\mathrm{Au} / \alpha-\mathrm{Fe}_{2} \mathrm{O}_{3}(\mathrm{R})$ gives rise to a more hemispherical shape of the gold particles. The presence of less-coordinated sites at the corrugated surface of $\alpha-\mathrm{Fe}_{2} \mathrm{O}_{3}(\mathrm{R})$ can explain this. During deposition-precipitation, gold was precipitated onto the surface of hematite. We considered that surface defects like Lewis acid sites due to coordinatively unsaturated Fe sites can act as anchoring sites for gold during deposition. Accordingly, we probed such sites at the surface by IR spectroscopy of adsorbed pyridine for the bare supports (Fig. S2). The band at $\sim 1445 \mathrm{~cm}^{-1}$ associated with Lewis acid sites is stronger for $\alpha-\mathrm{Fe}_{2} \mathrm{O}_{3}(\mathrm{R})$ than for $\alpha-\mathrm{Fe}_{2} \mathrm{O}_{3}(\mathrm{~S})$. The surface density of these sites is nearly two times higher on $\alpha-\mathrm{Fe}_{2} \mathrm{O}_{3}(\mathrm{R})\left(1.1 \mu \mathrm{mol} / \mathrm{m}^{2}\right)$ than on $\alpha-\mathrm{Fe}_{2} \mathrm{O}_{3}(\mathrm{~S})\left(0.61 \mu \mathrm{mol} / \mathrm{m}^{2}\right)$. The higher surface density of Lewis acid sites, which can stabilize gold on $\alpha-\mathrm{Fe}_{2} \mathrm{O}_{3}(\mathrm{R})$, provides a tentative explanation for the different dispersion and stability observed in the catalytic experiments.

We first evaluated the catalytic activity of the $\alpha-\mathrm{Fe}_{2} \mathrm{O}_{3}(\mathrm{~S})$ and $\alpha-\mathrm{Fe}_{2} \mathrm{O}_{3}(\mathrm{R})$ supports in $\mathrm{CO}$ oxidation (Fig. 4). These two supports were inactive below a temperature of $150{ }^{\circ} \mathrm{C}$. In the 150-300 ${ }^{\circ} \mathrm{C}$ range, $\mathrm{Fe}_{2} \mathrm{O}_{3}(\mathrm{R})$ displayed a higher activity than $\alpha-\mathrm{Fe}_{2} \mathrm{O}_{3}(\mathrm{~S})$. Apparent activation energies were determined to be 77 and $56 \mathrm{~kJ} / \mathrm{mol}$ for $\alpha-\mathrm{Fe}_{2} \mathrm{O}_{3}(\mathrm{~S})$ and $\alpha-\mathrm{Fe}_{2} \mathrm{O}_{3}(\mathrm{R})$, respectively. This difference points to the presence of different active
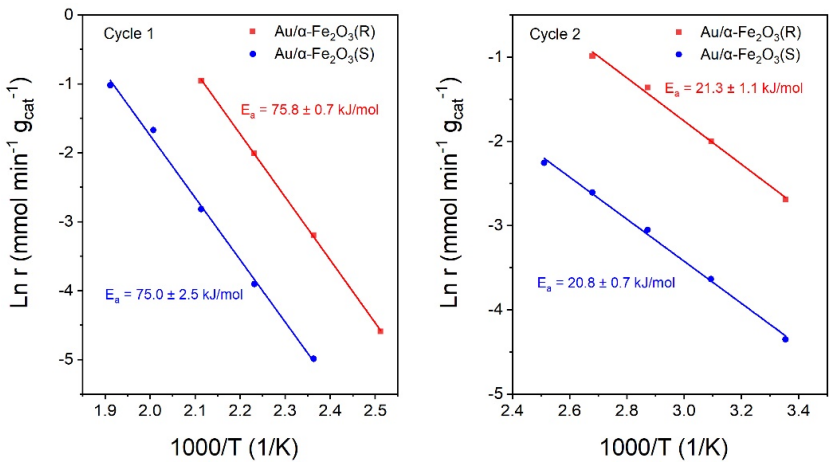

Fig. 6. Arrhenius plots of $\mathrm{Au} / \alpha-\mathrm{Fe}_{2} \mathrm{O}_{3}(\mathrm{~S})$ and $\mathrm{Au} / \alpha-\mathrm{Fe}_{2} \mathrm{O}_{3}(\mathrm{R})$ in two reaction cycles in $\mathrm{CO}$ oxidation.

sites between these two supports and is likely related to the presence of defect sites at the $\alpha-\mathrm{Fe}_{2} \mathrm{O}_{3}(\mathrm{R})$ surface, which is in line with the observation of a more corrugated surface structure. Such defect sites might present sites with lower oxygen binding energies relevant to the formation of $\mathrm{CO}_{2}$ in the catalytic $\mathrm{CO}$ oxidation cycle.

The catalytic activities of the fresh $\mathrm{Au} / \alpha-\mathrm{Fe}_{2} \mathrm{O}_{3}(\mathrm{~S})$ and $\mathrm{Au} / \alpha-\mathrm{Fe}_{2} \mathrm{O}_{3}(\mathrm{R})$ samples were also examined. Fig. 5 shows the conversion of $\mathrm{CO}$ as a function of reaction temperature in three consecutive cycles. In the first cycle, these two catalysts showed negligible activities below $125{ }^{\circ} \mathrm{C}$. At higher temperature, $\mathrm{Au} / \alpha-\mathrm{Fe}_{2} \mathrm{O}_{3}(\mathrm{R})$ was more active than $\mathrm{Au} / \alpha-\mathrm{Fe}_{2} \mathrm{O}_{3}(\mathrm{~S})$, with full conversion of $\mathrm{CO}$ being achieved at 225 and $275^{\circ} \mathrm{C}$, respectively. The activities of these two gold catalysts were remarkably higher in the second cycle. The improvement was more pronounced for $\mathrm{Au} / \alpha-\mathrm{Fe}_{2} \mathrm{O}_{3}(\mathrm{R})$. This sample was already active at $25{ }^{\circ} \mathrm{C}(12 \%$ conversion $)$ and gave a CO conversion of $98 \%$ at $125{ }^{\circ} \mathrm{C}$. In contrast, the activity increase was lower for $\mathrm{Au} / \alpha-\mathrm{Fe}_{2} \mathrm{O}_{3}(\mathrm{~S})$, showing a CO conversion of only $17 \%$ at $125^{\circ} \mathrm{C}$. The activities obtained in the third cycle were comparable to those in the second one for both catalysts. Fig. 6 shows the Arrhenius plots for $\mathrm{Au} / \alpha-\mathrm{Fe}_{2} \mathrm{O}_{3}(\mathrm{~S})$ and $\mathrm{Au} / \alpha-\mathrm{Fe}_{2} \mathrm{O}_{3}(\mathrm{R})$ in the first and second cycle. The apparent activation energies were significantly lower in the second cycle compared to the first one ( 21 vs. $75 \mathrm{~kJ} / \mathrm{mol}$ ), which can be explained by the activation of gold during the first reaction cycle. The similar apparent activation energies derived for $\mathrm{Au} / \alpha-\mathrm{Fe}_{2} \mathrm{O}_{3}(\mathrm{~S})$ and $\mathrm{Au} / \alpha-\mathrm{Fe}_{2} \mathrm{O}_{3}(\mathrm{R})$
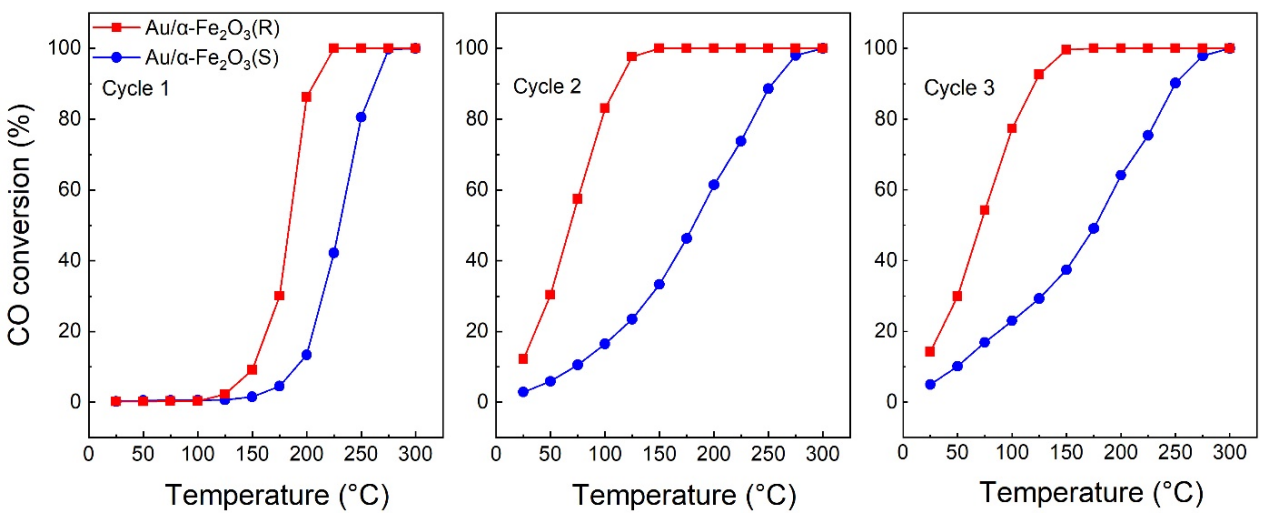

Fig. 5. $\mathrm{CO}$ oxidation activity of fresh $\mathrm{Au} / \alpha-\mathrm{Fe}_{2} \mathrm{O}_{3}(\mathrm{~S})$ and $\mathrm{Au} / \alpha-\mathrm{Fe}_{2} \mathrm{O}_{3}(\mathrm{R})$. Pretreatment conditions: $50 \mathrm{ml} / \mathrm{min} \mathrm{He}, 25{ }^{\circ} \mathrm{C}, 2 \mathrm{~h}$; Reaction conditions: 50 mg catalyst, 1 vol\% $\mathrm{CO}, 1$ vol $\% \mathrm{O}_{2}$ balanced with He, total flow rate $50 \mathrm{ml} / \mathrm{min}$. 


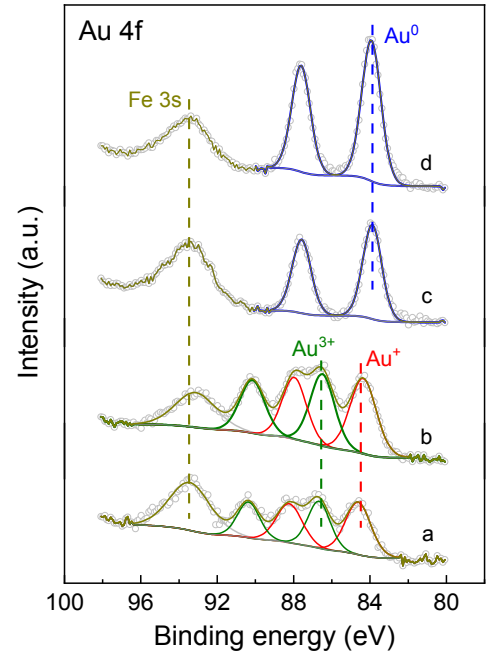

Fig. 7. $\mathrm{Au} 4 f \mathrm{XPS}$ spectra of different samples. (a) fresh $\mathrm{Au} / \alpha-\mathrm{Fe}_{2} \mathrm{O}_{3}(\mathrm{~S})$; (b) fresh $\mathrm{Au} / \alpha-\mathrm{Fe}_{2} \mathrm{O}_{3}(\mathrm{R}) ;$ (c) used $\mathrm{Au} / \alpha-\mathrm{Fe}_{2} \mathrm{O}_{3}(\mathrm{~S}) ;$ (d) used $\mathrm{Au} / \alpha-\mathrm{Fe}_{2} \mathrm{O}_{3}(\mathrm{R})$.

indicate that the hematite-supported gold catalysts follow a similar reaction mechanism in CO oxidation.

Considering that both gold catalysts were only pretreated in an inert helium flow at $25{ }^{\circ} \mathrm{C}$ after preparation, we speculate that the gold oxidation states changed during the first reaction cycle, leading to a higher catalytic performance in the second one. Thus, we carried out XPS surface analysis of the fresh and used gold catalysts. Fig. 7 shows that the gold phase in the fresh catalysts was predominantly present in the form of $\mathrm{Au}^{+}$and $\mathrm{Au}^{3+}$, whereas metallic gold $\left(\mathrm{Au}^{0}\right)$ was present in the used catalysts. Combining the Au XPS results with the activity data, we infer that the activation behavior during the first reaction cycle is due to the reduction of positively charged gold to metallic gold nanoparticles. Thus, we infer that $\mathrm{Au}^{0}$ is the more active form of gold for $\mathrm{CO}$ oxidation for $\alpha-\mathrm{Fe}_{2} \mathrm{O}_{3}$-supported gold catalysts in comparison to cationic gold. This conclusion is consistent with the general notion that highly active gold in

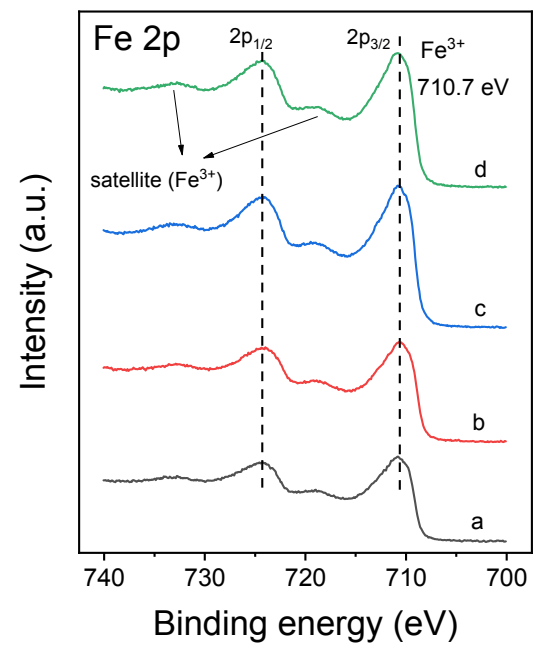

Fig. 8. Fe $2 p$ XPS spectra of different samples. (a) fresh $\mathrm{Au} / \alpha-\mathrm{Fe}_{2} \mathrm{O}_{3}(\mathrm{~S})$; (b) fresh $\mathrm{Au} / \alpha-\mathrm{Fe}_{2} \mathrm{O}_{3}(\mathrm{R})$; (c) used $\mathrm{Au} / \alpha-\mathrm{Fe}_{2} \mathrm{O}_{3}(\mathrm{~S}) ; \quad$ (d) used $\mathrm{Au} / \alpha-\mathrm{Fe}_{2} \mathrm{O}_{3}(\mathrm{R})$.
$\mathrm{Au} / \mathrm{Fe}_{2} \mathrm{O}_{3}$ is metallic [23]. The Fe $2 p$ XPS spectra shown in Fig. 8 demonstrate that $\mathrm{Fe}^{3+}$ is the dominant $\mathrm{Fe}$ species in fresh and used catalysts, which is expected.

To investigate possible morphological changes of the $\alpha-\mathrm{Fe}_{2} \mathrm{O}_{3}$ supports and changes in the size of the AuNPs during CO oxidation, SEM, TEM and STEM were used to characterize the used catalysts. Fig. S3 evidences that the rod- and sphere-like shapes of the two supports were preserved during the catalytic reaction. Based on TEM and STEM results (Fig. 9 and Fig. S4), it was found that the AuNPs sintered significantly on $\mathrm{Au} / \alpha-\mathrm{Fe}_{2} \mathrm{O}_{3}(\mathrm{~S})$, their average size increasing from $2.0 \mathrm{~nm}$ in the fresh sample to $4.0 \mathrm{~nm}$ after the $\mathrm{CO}$ oxidation reaction. The shape of the gold particles confirms the weak interaction with the support as discussed above for the fresh catalysts. In contrast, gold sintering was less pronounced for $\mathrm{Au} / \alpha-\mathrm{Fe}_{2} \mathrm{O}_{3}(\mathrm{R})$. AuNPs grew only slightly from 1.5 to $2.4 \mathrm{~nm}$ during the catalytic reaction and the EM images also confirm the retention of the
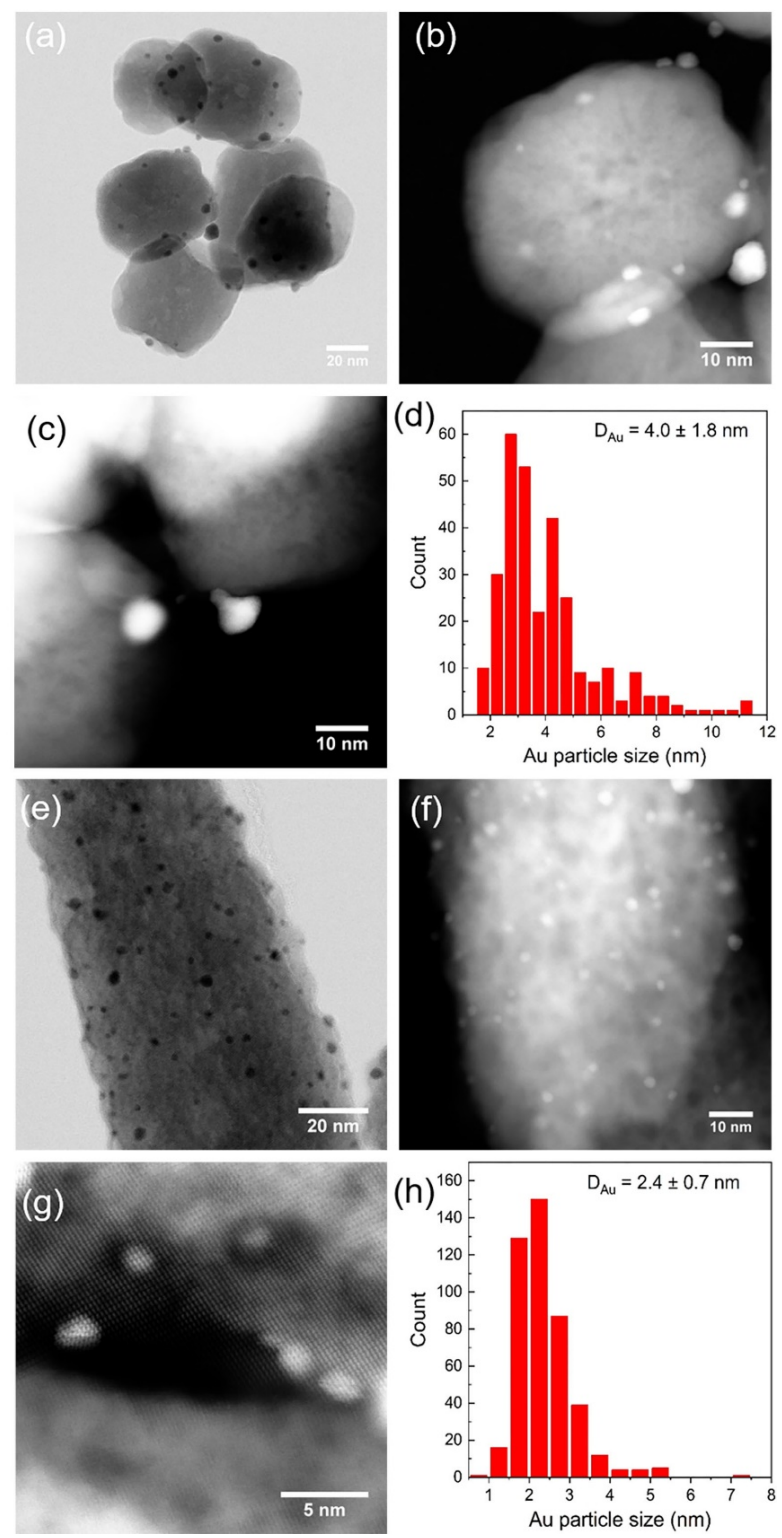

Fig. 9. TEM and HAADF-STEM images of used $\mathrm{Au} / \alpha-\mathrm{Fe}_{2} \mathrm{O}_{3}(\mathrm{~S})(\mathrm{a}-\mathrm{d})$ and $\mathrm{Au} / \alpha-\mathrm{Fe}_{2} \mathrm{O}_{3}(\mathrm{R})(\mathrm{e}-\mathrm{h})$ catalysts. 


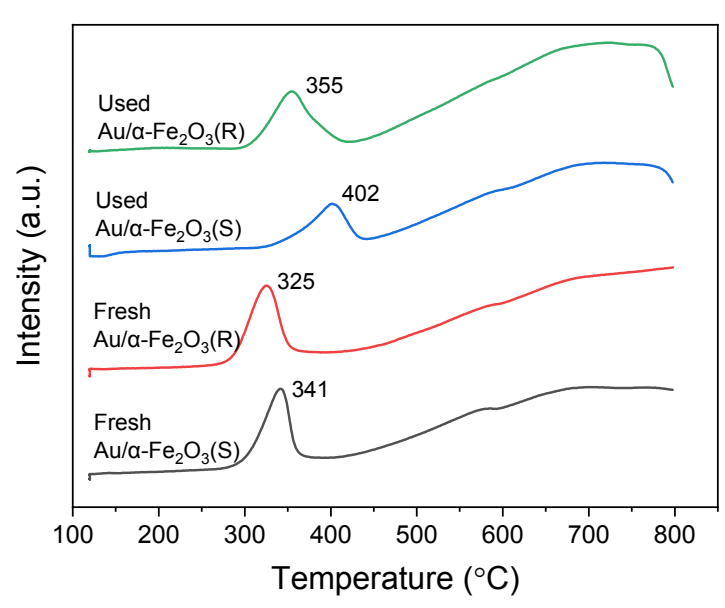

Fig. 10. $\mathrm{H}_{2}$-TPR spectra of fresh and used $\mathrm{Au} / \alpha-\mathrm{Fe}_{2} \mathrm{O}_{3}$ catalysts.

stronger interactions between gold and $\alpha-\mathrm{Fe}_{2} \mathrm{O}_{3}(\mathrm{R})$. On this basis, we can conclude that the stronger metal-support interactions led to a better resistance against sintering of the active gold phase on $\mathrm{Au} / \alpha-\mathrm{Fe}_{2} \mathrm{O}_{3}(\mathrm{R})$ in comparison with $\mathrm{Au} / \alpha-\mathrm{Fe}_{2} \mathrm{O}_{3}(\mathrm{~S})$. The much smaller AuNP size of $\mathrm{Au} / \alpha-\mathrm{Fe}_{2} \mathrm{O}_{3}(\mathrm{R})$ should be an important reason for its superior catalytic performance to $\mathrm{Au} / \alpha-\mathrm{Fe}_{2} \mathrm{O}_{3}(\mathrm{~S})$.

Besides the size of AuNPs, the redox properties of the support can be a critical factor governing the catalytic activity of gold catalysts in $\mathrm{CO}$ oxidation. Thus, we conducted $\mathrm{H}_{2}$-TPR to investigate the reducibility of the supports and gold catalysts. For $\alpha-\mathrm{Fe}_{2} \mathrm{O}_{3}(\mathrm{~S})$ and $\alpha-\mathrm{Fe}_{2} \mathrm{O}_{3}(\mathrm{R})$, the reduction features at 458 and $496{ }^{\circ} \mathrm{C}$ correspond to the reduction of hematite to magnetite $\left(\mathrm{Fe}_{3} \mathrm{O}_{4}\right)$ (Fig. S5). The reduction features at higher temperatures can be assigned to the reduction of magnetite through $\mathrm{FeO}$ towards metallic Fe [35]. The presence of gold significantly enhanced the reducibility of $\alpha-\mathrm{Fe}_{2} \mathrm{O}_{3}$. A strong reduction feature was observed at 341 and $325{ }^{\circ} \mathrm{C}$ for fresh $\mathrm{Au} / \alpha-\mathrm{Fe}_{2} \mathrm{O}_{3}(\mathrm{~S})$ and $\mathrm{Au} / \alpha-\mathrm{Fe}_{2} \mathrm{O}_{3}(\mathrm{R})$, respectively (Fig. 10). We attribute this to hydrogen activated on gold spilling over to the support surface and, thereby, promoting Fe-oxides reduction. This is commonly observed for metal particles on a reducible oxide support such as $\mathrm{Au} / \mathrm{CeO}_{2}$ [28]. For used $\mathrm{Au} / \alpha-\mathrm{Fe}_{2} \mathrm{O}_{3}(\mathrm{~S})$, the reduction peak shifted to a much higher temperature of $402{ }^{\circ} \mathrm{C}$, which can be explained by a smaller perimeter interface between the significantly larger gold nanoparticles and the support. This shift is much smaller for used $\mathrm{Au} / \alpha-\mathrm{Fe}_{2} \mathrm{O}_{3}$ (R), i.e. from 325 to $355^{\circ} \mathrm{C}$. The small shift is in line with the much smaller loss in gold dispersion for $\mathrm{Au} / \alpha-\mathrm{Fe}_{2} \mathrm{O}_{3}(\mathrm{R})$.

The above characterization of the fresh and used $\mathrm{Au} / \alpha-\mathrm{Fe}_{2} \mathrm{O}_{3}(\mathrm{~S})$ and $\mathrm{Au} / \alpha-\mathrm{Fe}_{2} \mathrm{O}_{3}(\mathrm{R})$ clearly demonstrates that the morphology of $\alpha-\mathrm{Fe}_{2} \mathrm{O}_{3}$ has a great influence on the structure of gold, i.e., the interface between gold and $\alpha-\mathrm{Fe}_{2} \mathrm{O}_{3}$ depends on the surface structure of $\alpha-\mathrm{Fe}_{2} \mathrm{O}_{3}$. Gold is bound stronger to $\alpha-\mathrm{Fe}_{2} \mathrm{O}_{3}(\mathrm{R})$, which leads to a more hemispherical shape of the gold particles. We explain this by the observed corrugated surface of $\alpha-\mathrm{Fe}_{2} \mathrm{O}_{3}(\mathrm{R})$. Low-coordinated Fe atoms being Lewis acid sites can serve as anchoring sites to stabilize the gold particles. The presence of more reactive Fe sites can also contribute to a higher $\mathrm{CO}$ oxidation activity of $\mathrm{Au} / \alpha-\mathrm{Fe}_{2} \mathrm{O}_{3}(\mathrm{R})$. On the other hand, spherical gold particles were present on $\alpha-\mathrm{Fe}_{2} \mathrm{O}_{3}(\mathrm{~S})$, indicative of a weaker interaction between gold and the support, likely because there are less defects on the surface of $\alpha-\mathrm{Fe}_{2} \mathrm{O}_{3}(\mathrm{~S})$. This led to more extensive gold aggregation during the catalytic reaction.

\section{Conclusions}

Nanosphere and nanorod hematite $\left(\alpha-\mathrm{Fe}_{2} \mathrm{O}_{3}(\mathrm{~S})\right.$ and $\alpha-\mathrm{Fe}_{2} \mathrm{O}_{3}(\mathrm{R})$ ) were synthesized through a hydrothermal method, and used as supports for gold nanoparticles. The surface of $\alpha-\mathrm{Fe}_{2} \mathrm{O}_{3}(\mathrm{R})$ was more corrugated than the surface of $\alpha-\mathrm{Fe}_{2} \mathrm{O}_{3}(\mathrm{~S})$. These defects can provide anchoring sites for gold deposition and gold particle stabilization. The dispersion of gold species and their interaction with $\alpha-\mathrm{Fe}_{2} \mathrm{O}_{3}$ are strongly dependent on the $\alpha-\mathrm{Fe}_{2} \mathrm{O}_{3}$ morphology. The gold-support interaction is stronger for $\mathrm{Au} / \alpha-\mathrm{Fe}_{2} \mathrm{O}_{3}(\mathrm{R})$ as evidenced by the more hemispherical shape of the supported gold particles and the more uniform distribution over the surface. Gold sintering was significantly suppressed during $\mathrm{CO}$ oxidation. In contrast, the weaker interaction of gold with $\alpha-\mathrm{Fe}_{2} \mathrm{O}_{3}(\mathrm{~S})$ led to a non-uniform distribution and severe sintering of gold during CO oxidation. The smaller gold particle size, the stronger metal-support interaction, and the better reducibility contributed to the higher $\mathrm{CO}$ oxidation activity of $\mathrm{Au} / \alpha-\mathrm{Fe}_{2} \mathrm{O}_{3}(\mathrm{R})$.

\section{References}

[1] S. A. C. Carabineiro, Front. Chem., 2019, 7, 702.

[2] S. E. Davis, M. S. Ide, R. J. Davis, Green Chem., 2013, 15, 17-45.

[3] Y. Gao, E. J. M. Hensen, Catal. Commun., 2018, 117, 53-56.

[4] Y. Gao, L. Zhang, A. J. Van Hoof, H. Friedrich, E. J. M. Hensen, ACS Catal., 2019, 9, 11104-11115.

[5] A. Stephen, K. Hashmi, G. J. Hutchings, Angew. Chem. Int. Ed., 2006, 45, 7896-7936.

[6] A. A. Herzing, C. J. Kiely, A. F. Carley, P. Landon, G. J. Hutchings, Science, 2008, 321, 1331-1335.

[7] T. Ishida, T. Murayama, A. Taketoshi, M. Haruta, Chem. Rev., 2020, 120, 464-525.

[8] S. Yamazoe, K. Koyasu, T. Tsukuda, Acc. Chem. Res., 2013, 47, 816-824.

[9] S. Chen, L. Luo, Z. Jiang, W. Huang, ACS Catal., 2015, 5, 1653-1662.

[10] J. A. Hernández, S. A. Gómez, T. A. Zepeda, J. C. Fierro-González, G. A. Fuentes, ACS Catal., 2015, 5, 4003-4012.

[11] D. Widmann, R. Leppelt, R. J. Behm, J. Catal., 2007, 251, 437-442.

[12] S. Zhang, X. S. Li, B. Chen, X. Zhu, C. Shi, A. -M. Zhu, ACS Catal., 2014, 4, 3481-3489.

[13] I. X. Green, W. Tang, M. Neurock, J. T. Yates, Science, 2011, 333, 736-739.

[14] A. Y. Klyushin, M. T. Greiner, X. Huang, T. Lunkenbein, X. Li, O. Timpe, M. Friedrich, M. Hävecker, A. Knop-Gericke, R. Schlögl, ACS Catal, 2016, 6, 3372-3380.

[15] A. Sandoval, C. Louis, R. Zanella, Appl. Catal. B, 2013, 140, 363-377.

[16] S. Wei, W. W. Wang, X. P. Fu, S. Q. Li, C. J. Jia, J. Catal., 2019, 376, 134-145.

[17] D. Gu, J. C. Tseng, C. Weidenthaler, H. J. Bongard, B. Spliethoff, W. 


\title{
Graphical Abstract
}

Chin. J. Catal., 2021, 42: 658-665 doi: 10.1016/S1872-2067(20)63687-7

Influence of hematite morphology on the CO oxidation performance of $\mathrm{Au} / \alpha-\mathrm{Fe}_{2} \mathrm{O}_{3}$

Yanan Gao, Fu-Kuo Chiang, Shaojie Li, Long Zhang, Peng Wang, Emiel J. M. Hensen *

Eindhoven University of Technology, The Netherlands; National Institute of Clean-and-Low-Carbon Energy, China

The hematite morphology has a substantial influence on the interaction with nanoparticulate gold. Smaller and more sintering-resistant gold particles with hemispherical shape are obtained on rod-shaped $\mathrm{Au} / \mathrm{Fe}_{2} \mathrm{O}_{3}(\mathrm{R})$, displaying significantly higher $\mathrm{CO}$

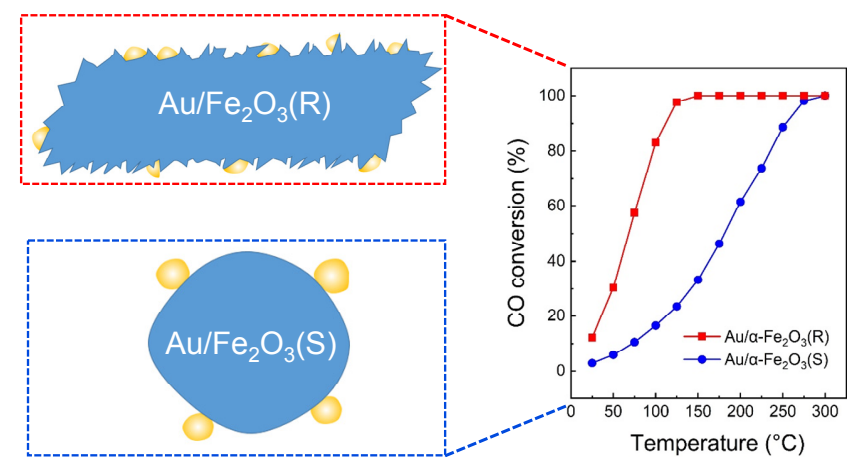
oxidation activity in comparison to sphere-shaped $\mathrm{Au} / \mathrm{Fe}_{2} \mathrm{O}_{3}(\mathrm{~S})$.

Schmidt, F. Soulimani, B. M. Weckhuysen, F. Schüth, J. Am. Chem. Soc., 2016, 138, 9572-9580.

[18] L. C. Wang, X. S. Huang, Q. Liu, Y. M. Liu, Y. Cao, H. Y. He, K. N. Fan, J. H. Zhuang, J. Catal., 2008, 259, 66-74.

[19] L. C. Wang, Q. Liu, X. S. Huang, Y. M. Liu, Y. Cao, K. N. Fan, Appl. Catal. B, 2009, 88, 204-212.

[20] T. Akita, Y. Maeda, M. Kohyama, J. Catal., 2015, 324, 127-132.

[21] S. Minico, S. Scire, C. Crisafulli, A. M. Visco, S. Galvagno, Catal. Lett., 1997, 47, 273-276.

[22] B. Qiao, J. X. Liang, A. Wang, C. Q. Xu, J. Li, T. Zhang, J. J. Liu, Nano Res., 2015, 8, 2913-2924.

[23] X. Wei, B. Shao, Y. Zhou, Y. Li, C. Jin, J. Liu, W. Shen, Angew. Chem. Int. Ed., 2018, 57, 11289-11293.

[24] L. Zeng, K. Li, H. Wang, H. Yu, X. Zhu, Y. Wei, P. Ning, C. Shi, Y. Luo, J. Phys. Chem. C, 2017, 121, 12696-12710.

[25] K. Zhao, H. Tang, B. Qiao, L. Li, J. Wang, ACS Catal., 2015, 5, 3528-3539.

[26] S. Carrettin, P. Concepción, A. Corma, J. M. Lopez Nieto, V. F.
Puntes, Angew. Chem. Int. Ed., 2004, 43, 2538-2540.

[27] H. Ha, S. Yoon, K. An, H. Y. Kim, ACS Catal., 2018, 8, 11491-11501.

[28] X. S. Huang, H. Sun, L. C. Wang, Y. M. Liu, K. N. Fan, Y. Cao, Appl. Catal. B, 2009, 90, 224-232.

[29] G. Yi, Z. Xu, G. Guo, K.-I. Tanaka, Y. Yuan, Chem. Phys. Lett., 2009, $479,128-132$.

[30] G. Yi, H. Yang, B. Li, H. Lin, K.-i. Tanaka, Y. Yuan, Catal. Today, 2010, $157,83-88$.

[31] K. Jia. H. Zhang, W. Li, Chin. J. Catal, 2008, 29, 1089-1092.

[32] L. Gu, Q. Su, W. Jiang, Y. Yao, Y. Pang, W. Ji, C.-T. Au, Catal. Sci. Technol., 2018, 8, 5782-5793.

[33] C. J. Jia, L. D. Sun, Z. G. Yan, L. P. You, F. Luo, X. D. Han, Y. C. Pang, Z. Zhang, C. H. Yan, Angew. Chem. Int. Ed., 2005, 44, 4328-4333.

[34] R. Zanella, S. Giorgio, C. R. Henry, C. Louis, J. Phys. Chem. B, 2002, $106,7634-7642$.

[35] Q. He, S. J. Freakley, J. K. Edwards, A. F. Carley, A. Y. Borisevich, Y. Mineo, M. Haruta, G. J. Hutchings, C. J. Kiely, Nat. Commun., 2016, 7, 12905 .

\section{$\alpha-\mathrm{Fe}_{2} \mathrm{O}_{3}$ 形貌对 $\mathrm{Au} / \alpha-\mathrm{Fe}_{2} \mathrm{O}_{3}$ 催化一氧化碳氧化反应性能的影响}

\author{
Yanan Gao $^{\text {a, }}$ Fu-Kuo Chiang ${ }^{b}$, Shaojie Li ${ }^{\text {a }}$, Long Zhang ${ }^{\text {a }}$, Peng Wang ${ }^{\text {a,b }}$, Emiel J. M. Hensen ${ }^{\text {a,* }}$ \\ 埃因霍温理工大学化学工程与化学学院, 无机材料与催化实验室, 埃因霍温, 荷兰 \\ b北京低碳清洁能源研究院, 未来科学城, 北京102211, 中国
}

摘要: 负载型纳米金催化剂由于其独特的化学性质在一系列氧化反应中受到广泛关注. 其中, 一氧化碳氧化不仅在实际应 用领域(如汽车尾气处理)发挥重要作用, 而且作为一种理想的模型反应用以深入研究和理解催化剂的构效关系. 为了获得 高效的纳米金催化剂, 我们需要把金负载到载体上, 载体不仅为金的分散提供必要的表面, 而且还会和金产生相互作用, 这 种金属-载体相互作用对金的氧化态, 金颗粒大小及其热稳定性均有重要影响.

金属氧化物是负载金最常用的载体. 为了提高纳米金催化剂的性能, 需要调变金属氧化物的性质. 常用的策略是调控 金属氧化物的组成、晶相以及晶粒大小. 此外, 对金属氧化物的形貌进行精细调控也是一种重要的方法, 因为具有不同形 貌的氧化物可能会暴露出不同的晶面, 而且可能具有不同的缺陷位点. $\alpha-\mathrm{Fe}_{2} \mathrm{O}_{3}$ 是一种热稳定性强而且对环境友好的载体, 可是有关其形貌对负载金催化剂在一氧化碳氧化反应中性能影响的研究尚不充分. 因此, 本文采用水热法合成了具有纳 米球和纳米棒两种形貌的氧化铁, 并采用沉积-沉淀的方法将金纳米颗粒负载于其表面. 高分辨透射电镜照片显示, 和氧化 
铁纳米球 $\left(\alpha-\mathrm{Fe}_{2} \mathrm{O}_{3}(\mathrm{~S})\right)$ 相比, 氧化铁纳米棒 $\left(\alpha-\mathrm{Fe}_{2} \mathrm{O}_{3}(\mathrm{R})\right)$ 的表面更为粗糙, 具有更多的缺陷位点. $\mathrm{Au}$ 和 $\alpha-\mathrm{Fe}_{2} \mathrm{O}_{3}(\mathrm{R})$ 之间有更强 的金属载体相互作用, 导致纳米棒氧化铁上的金纳米颗粒更小而且多呈半球形. 相比之下, 纳米球氧化铁上的金纳米颗粒 较大, 多呈球形, 且分布不均匀. 反应结果表明, $\mathrm{Au} / \alpha-\mathrm{Fe}_{2} \mathrm{O}_{3}(\mathrm{R})$ 具有更高的一氧化碳氧化活性. 对反应后的催化剂进行表征 发现, $\mathrm{Au} / \alpha-\mathrm{Fe}_{2} \mathrm{O}_{3}(\mathrm{R})$ 上金颗粒烧结程度较低, 平均粒径从 1.5 增至 $2.4 \mathrm{~nm}$, 而 $\mathrm{Au} / \alpha-\mathrm{Fe}_{2} \mathrm{O}_{3}(\mathrm{~S})$ 上金颗粒烧结较为严重, 平均粒径 从 $2.0 \mathrm{~nm}$ 增加到 $4.0 \mathrm{~nm}$. 氢气程序升温还原结果表明, $\mathrm{Au} / \alpha-\mathrm{Fe}_{2} \mathrm{O}_{3}$ ( R) 具有更强的还原性, 这也促进了其催化活性的提高.

关键词: 金; 一氧化碳氧化; $\alpha-\mathrm{Fe}_{2} \mathrm{O}_{3}$; 形貌; 稳定性

收稿日期: 2020-05-01. 接受日期: 2020-06-05. 上网日期: 2020-09-05.

*通讯联系人. 电子信箱: e.j.m.hensen@tue.nl

本文的电子版全文由Elsevier出版社在ScienceDirect上出版(http://www.sciencedirect.com/science/journal/18722067). 